relating to the etiology of tuberculosis. The author repeated the inoculation experiments of Koch, with similar results. The experiments of Formad to induce tuberculosis in rabbits by introducing into the cavity of the abdomen finely powdered inorganic material, have also been repeated with entirely negative results. The author held that Koch's bacillus was an cssential factor in the etiology of tuberculosis.

Dr. C. E. Bessey, in a paper on the adventitious inflorescence of Cuscuta glomsrata, stated that the examination of young plants shows that the inflorescence is developed from numerous crowded adventitious buds, and not by the repeated branching of axillary flowering branches as commonly stated.

In a paper on the hitherto unknown mode of oviposition in the Carabidæ, Prof. C. V. Riley records habits of Chlenius impunctifrons, traced from the eggs up. The eggs are laid singly, in cells made of mud or clay, on the under surface of leaves.

Mrs. A. B. Blackwell read a paper on the comparative longevity of the sexes. The study was exhaustive, and made on statistics from all parts of the world ; and the greater longevity of woman over man was established. In old countries the females prepondcrate, while males lead in newly settled ones. Up to eighteen years the males are in excess of the females: later the females predominate in numbers.

\section{THE PRIME MERIDIAN CONFERENCE}

THE Prime Meridian Conference at Washington on Monday adopted the Greenwich line as the universal prime meridian. Only one vote--that of St. Domingo-was given against its adoption; but the representatives of France and Brazil declined to votc.

The following details of the session are from the Times Correspondent :-

To the American resolution for adopting the Greenwich line, Mr. Fleming (Canarla) moved an amendment to the effect that the Conference should adopt the I8oth degree of longitude east from Greenwich as the prime meridian; but the other British delegates opposing the proposition it was lost. Señor Valera, the Spanish Minister, said that he had been instructed by his Government, in voting for the meridian of Greenwich, to say that it hoped the metric system of weights and measures would be adopted by England, the United States, and the other nationalities therc represented, as recommended by the Conference at Rome. Gen. Strachey (Great Britain) said that he was authorised to statc that his country had asked to be allowed to join the Metrical Convention, and that the metric system was already recognised by the laws of Great Britain, and was in use for scientific purposes. He could not, however, say that it would be adopted in any circumstances as a popular system of weights and measures throughout England. M. Lefaivre (France) said the Greenwich was not a scicntific meridian, and that it implied no progress in any science, but was merely a commercial standard. Since, therefore, nothing would be gained to science by adopting Greenwich, France could not make a sacrifice of her own meridian, and incur the vast expense consequent upon the adoption of a new one, because she would thereby gain no advantage whatever. Sir William Thomson, who was present as a guest, by the invitation of the Conference, spoke in favour of the choice of Greenwich. He said that it was purely a matter of convenience, and that Greenwich answered the world's convenience better than any other standard meridian. Sir Frederick Evans (Great Britain) presented a statement showing that the shipping tonnage controlled by the Greenwich standard of longitude was about $14, \mathrm{COO}, 000$ tons, and that controlled by the I'aris one only $1,735,000$ tons. From the statement of chart sales, \&c., to nations outside England, he showed how largely the Greenwich measure was used.

The resolution recommending the choice of Greenwich was then adopted, the ayes being $2 \mathbf{r}$, and there being but one naySan Domingo. France and Brazil abstained from voting.

Mr. Rutherford (United States) moved that from the Greenwich meridian the longitude be counted in two directions, up to $180^{\circ}$, the east longitude being " pluts," and the west "minus." The Russian Minister advocated this proposal, but Count Lowenbaupt (Sweden) moved the adoption of the fourth resolution of the Roman Conference for counting longitude continuously through the whole $360^{\circ}$. Herr von Alvensleben (Germany) said that this was a matter of detail, and therefore he should not vote upon it. The British delegates agreed with the Ger- man Minister that this was a matter of detail, and held that it would not make any difference which method was adopted. Señor Juan Pastorian (Spain) stated that he favoured the plan of counting longitude westward continuously round the world.

The discussion was here adjourned.

\section{UNIVERSITY AND EDUCATIONAL INTELLIGENCE}

OXFORD.--The beginning of Michaelmas Term shows that the University and Colleges have not been idle in erecting new buildings for the accommodation of students. The new buildings of Magdalen - to be called the Waynflete Buildings-are ready for occupation, and will be used this term. No one can deny that the most beautiful of Oxford Colleges has added a new ornament to the city in the Waynflete Buildings. The new buildings of Trinity College are rapidly approaching completion. Stretching back from quaint old Kettle Hall in Broad Street, they extend to near the bcginning of the Lime Walk in the College Garden. The open space in front of the Collegeknown as Trinity Green-will now be bounded on the east by these new buildings. The Green will thus become one of the largest "quads" in Oxford. On the north side of the University Museum the new Physiological Laboratory is rising. Its situation is one of the pleasantest in Oxford. That Prof. Burdon-Sanderson is attracting pupils to physiology is a patent fact in Oxford, and one that will be received outside that city with the strongest feeling of satisfaction.

Since last Term we have to deplore the loss of Mark Pattison, Rector of Lincoln Collcge. Mr. Merry, Public Orator in the University, and Fellow and Tutor of the College, has been elected his successor.

The following scheme of lectures and classes has been agreed on by the Board of the Natural Science Faculty :-

In the Department of Physics Prof. Clifton will lecture on the Galvanometer and Methods of Measuring Electric Currents, and on Thermo-Electricity. Prof. Price will lecture on Optics, Physical and Geometrical. Prof. Clifton and Mr. Walker give instruction in Practical Physics in the Clarendon Laboratory. Mr. Walker will give a course on Ouestions incidental to the P'ractical Study of Mechanics and Heat. Mr. Baynes will give a course of lectures at Christ Church on Thermodynamics, and form a class for practical instruction in Magnetic and Electrical Measurements. Mr. Dixon will give a coursc of experimental lectures, on Elementary Heat and Light, at Balliol College. Prof. Pritchard will lecture on Spherical Astronomy, and form a class for practical work in the University Observatory

In the Department of Chemistry Prof. Odling will give a course of lectures on 3-carbon and 4-carbon compounds. Mr. Fisher will lecture on Inorganic, and Dr. Watts on Organic, Chemistry. At Christ Church Mr. Vernon Harcourt will form a class for Volumetric Analysis. Practical instruction in Chemistry is given daily in the Museum Laboratory, and in the Chemical Laboratories at Christ Church and Balliol College. Prof. Gilbert will complete his course on the Constitution of Plants, and will then lecture on the Effects of Manures, Exhaustion and Variations of Season on the Amounts of Produce and on the Composition of Wheat.

In the Morphological Department Prof. Moseley will begin his course of Comparative Anatomy; each lecture will be fol lowed by special demonstrations on the subject of the lecture. Dr. Hickson gives a course on the Morphology of the Vertebrata, each lecture to be followed by special demonstrations. Mr. Barclay Thompson lectures on the Anatomy of the Mam malia: Mr. Jackson on the Fundamental Principles of Comparative Embryology; Mr. Poulton on the Distribution of Animals; Mr. Morgan on Odontography and on Human Osteology. Prof. Westwood will lecture on the Insect Skeleton.

In the Department of Physiology Prof. Burdon-Sanderson will lecture on the Physiology of Circulation and Respiration. Practical instruction will be given in the Laboratory by the Professor, Dr. Dixie, and Dr. Gotch.

Prof. Bayley Balfour will give a course of lectures in the Botanic Garden, on the General Morphology of Plants.

Prof. Prestwich will lecture at the Museum on the Principles and Elements of Geology. Dr. Tylor will lecture on the Intel lectual Development of Mankind.

During the course of the present Michaelmas Term, Scholarships will be awarded in Natural Science at the following Colleges:-At Balliol College, without limitation of age; at 